\title{
Sharecropping Agreement in Accordance with Maqasid Al-Syariah
}

\author{
Muhammad Fajar Pramono $^{1 *}$, Mulyono Jamal ${ }^{1}$, Ruchhima ${ }^{1}$, Nur Azizah Latifah ${ }^{1}$ \\ ${ }^{1}$ University of Darussalam Gontor, Ponorogo, Indonesia \\ "Corresponding author.Email: mfpramono@unida.gontor.ac.id
}

\begin{abstract}
This research was conducted in Sambirejo village Ngawi, where the majority of the population worked as farmers and one of the systems by the community to cultivate land was the sharecropping system. The sharecropping agreement is carried out based on the traditions or customs in the village. The ratio is determined based on the planting season, not in the capital proportion. The agreement is carried out verbally and there is no period determination. The purpose of this study is to determine the implementation of the sharecropping system in the Sambirejo village and analyse its application according to Maqasid Syariah. This research uses the qualitative descriptive method with primary and secondary data obtained through observation, unstructured interviews and documentation. The results of the study indicate that the implementation of the sharecropping agreement, in general, is carried out according to the customs in the village, namely verbally and without determining the agreement period. The profit sharing ratios namely, mertelu, merpapat and moro limo are determined based on the planting season, except for maro. The determination of the profit sharing proportion is determined based on the provision of capital included in the agreement. If it is viewed based on the seeds provision, the sharecropping includes mukhabarah, because most of the farmers provide the seeds. However, the sharecropping agreement is not entirely in accordance with mukhabarah, especially in the capital contributions of seeds, the profit sharing proportion that is not in accordance with the capital provided and the time of the agreement that is not determined initially. Overall, the sharecropping agreement implemented by the community in Sambirejo village has been in line with the concept of muamalah in Islamic economic law; namely, there is a value of cooperation, honesty and justice between the two parties.
\end{abstract}

Keywords: sharecropping, mukhabarah, custom, Maqasid Syariah

\section{INTRODUCTION}

The sharecropping system has become a downward tradition that is used by rural communities [1]. is a solution for agricultural problems in society, such as land depreciation due to the conversion of agricultural land for housing; low employment opportunities in other sectors which results in increased employment in the agrarian sector; and limited area owned by farmers [2]. With the increasing number of cultivators, the sharecropping system is able to connect the needs of landowners for labor to cultivate their land with farmer groups that do not have agricultural land [3]. However, this can be seen from the fact that there are still many people using sharecropping systems in farming, especially in rural areas [4].

The sharecropping based on custom, is also applied by the community in Sambirejo village, where most of the people work as farmers. Based on village custom, the distribution of results is not shared proportionally. In practice the ratio is determined based on the planting season, not on the capital provision; the agreement is carried out verbally and there is no period determination.

\section{METHOD}

This research is qualitative research and data collection is carried out in triangulation, data analysis is inductive and the results of qualitative research emphasize the meaning rather than generalization [5]. So that research will be carried out by observing directly, which reality in the field will be used as primary sources. With the main object is the sharecropping agreement between landowners and farmers in Sambirejo village.

The analysis that will be used is descriptive analysis that is analyzing data by describing data that has been collected. In the early stages' researchers looked for facts about the concept of sharecropping by the community through observation, interviews, and documentation. After data collected the mass of data organized and reduced by selecting, focusing, and transforming data to transcriptions. After the data is reduced the author analyzes the results that have been collected by the sharecropping concept according to Islamic law.

This study only discusses the sharecropping in agriculture with the analysis of Maqasid Syariah consisting of maqashid dharuriyyah, haajiyyah and tahsiniyyah. The purpose of this study is to describe the definition of 
sharecropping in Islam and Maqasid Syariah in general, the practice of sharecropping agreements in Sambirejo village and the practice of sharecropping agreements in Sambirejo village according to the maqasid. The analysis tool used to analyse the proportion of sharecropping in Sambirejo village is Maqasid Syariah.

\subsection{The Definition of Sharecropping}

In Islamic law, profit sharing in agricultural business is called muzara'ah. Muzara'ah is derived from the word zara'a, which means crop [6]. In terms of muzara'ah, it means giving land to the farmer so that he gets a share of the crop. For example, one third, one half or more or less than that [7]. So the result of muzara'ah is a joint share of the crops between a landowner and farmer, with the profit sharing in accordance with a mutual agreement between the two parties.[8] The Malikis defined it as a partnership in crops. However, the Hanbalis defined it as a landlord giving a farmer access to work his land of plant it, with an agreement to share the crop [9].

The term muzara'ah is a form of contract (mu'amalah) between two parties, which is similar with the term mukhabarah. Mukhabara, is derived from khabara, which means fertile land, or muhaqala. The Shafi'is defined mukhabara as working the land in exchange for part of the produce, where the farmer provides all seeds [10]. Some jurists compare the term muzara'ah with the term Mukhabarah, with some considering them similar, while others making a distinction on the basis of who supplies the seeds needed for sowing or capital used in the partnership. If the plant seeds or the capital comes mostly from the landowner, then the sharecropping contract is muzara'ah. Whereas if the plant seeds or capital come mostly from the farmer, then the sharecropping contract is called mukhabarah [11].

In sharecropping outlined above, farmers and landowners in Sambirejo village use the sharecropping system because they indirectly feel the maslahah or the benefits of the profit sharing and the mutual benefits between the two parties. The scope of Shari'a is the main objective that can be accepted by all human beings and this goal is called maqashid as-sharia, according to the level of importance in human life. This can be implemented in three levels, namely dharuriyah, hajjiyah and tahsiniyah [12].

\subsubsection{The element}

The elements in the contract, according to the majority of Islamic jurisprudence scholars, are the parties who carried out the contract, the object of the contract and the offer and acceptance [13].

\subsubsection{The Conditions}

The legal requirements for mukhabarah are specifically found on both parties, crops, planting land, what is required and the term of the agreement. The following are the details of such requirements:

a. The parties' conditions

There are two conditions for those who do mukhabarah, namely: 'Sane'- the parties within the contract must be sane. If parties are not sane, do not fully understand mukhabarah and do not have the ability to issue or receive or make an agreement, then the contract is void. Because the ability to give and receive a valid condition for someone to do a legal act. Whereas bulugh (majority or legal age) is not a condition to be allowed to do mukhabarah contract.

b. The Seed

According to Hanafis and Hanbalis, the types of crop to be planted must be known, as well as the type and nature [14]. Therefore, it is required to explain the types of plants that will be planted to avoid a disadvantage. Once the landowner allows the farmer to plant crops in according to the wishes of the farmer, the farmer does not need to explain the type of crops to be planted [15].

c. The produce conditions

The agricultural produce is the result that will be distributed to both parties who carried out the mukhabarah contract, with the following conditions: The produce must be outlined at the beginning of the agreement to avoid a dispute. The produce must divided according unidentified shares such as half, one third, quarter, etc. [16].

d. The object of contract conditions

The object of the mukhabarah contract must be known, because ignorance causes disputes and hostility. First, the benefits of the workers become the object of mukhabarah. The benefits of employment become an object if the landowner provided the seed, because the landowner becomes the person who employs the farmer to work on his farm in return for a certain part of the crop. Second, the benefits of land can be an object if the seed comes from the farmer, because the farmer becomes the tenant of the land by paying the landowner with a portion of the yield that grows from the land.

e. The land conditions

Giving full access to the farmer to use the land for agriculture. If the contract includes a condition of the landowner to interfere in, then the mukhabarah contract would be deemed invalid.

f. The production tools conditions

The use of tools or livestock is not a purpose of the contract, but it must be a derivative of the contract. Thus, the mukhabarah contract would be deemed defective if the contract is written for the express purpose of using such tools or animals [17].

g. The period of contract conditions

The duration of mukhabarah must be known, since the contract is in essence a lease in exchange for crop share, because a lease is invalid if the period is unknown, so is mukhabarah [18]. The scholars of Islamic jurisprudence have different views as follows: According to Hanafis' opinion, the mukhabarah contract must have a time limit if it has not been determined; otherwise, if the time limit is unknown, then the mukhabarah contract becomes vitiated, because mukhabarah is a rent with result from the produce and ijarah is invalid if the time is unknown. 
The condition is required to determine sufficient time limits for planting until harvesting and allowing it to carry out mukhabarah for many years with an explanation and limitations regarding the time of the agreement. Some Hanafis believe that it is illegitimate if the time of the contract is not explained. According to Hanbalis, there is no requirement for an explanation of the time limit of the muzara'a contract, because the Prophet did not mention the time for the Khaibar.

\subsection{The definition of maqasid al-syariah}

Maqashid sharia consists of two words, namely maqasid and syariah. Maqashid means intention or purpose; maqashid is a form of maqsud derived from the word qashada, which means desire or meaning. Maqashid means things that are intended and intended [19]. According to the term: according to the jurist, there is no special discussion in maqashid sharia, in order to understand and interpret the knowledge of maqashid sharia in detail; however, only in the writing of some maqashid syariah or only of types [20]. According to Muhammad 'Abdul'atii, the scholars have not understood maqashid sharia as their level of understanding of the topics that are in accordance with their knowledge, then according to as-satibi as the Sheikh of scholars in the maqashid, there is no clear limitation. However, the imam al-syatibi has not written his book specifically in the maqashid according to human approval in general; however, the imam al-syatibi is an expert in sharia science and has a lot of understanding about maqashid sharia [21]. As it relates to the opinion of the Islamic scholars in the classification of Maqashid syari'ah, Ghazali mentioned that the purpose of Shari'a is to maintain 5 aspects, namely religion, soul, 'aql, heredity and wealth. So whoever cares for these 5 bases, will get the benefit/safety and if one of them is lost, then there will be damage done. The purpose described to guard against damage and bring to the maslahah [22].

According to ulama al-Syatibi as Sheikh in the maqashid syariah said, the benefits that will be realised are divided into three levels, namely the need for dharuriyat, hajiyat and tahsiniyat. According to al-Syatibi, there are five things that fall into the category of necessity of dharuriyat i.e. maintaining religion, soul, intellect, ancestry and wealth. To preserve these five points, Islamic law is revealed [23]. In general, the maqashid syariah is divided into 2 parts: [first], the maqashid returned to the intentions of syar' $i$. The purpose of syar' $i$ here is to lower the law to the creature by one cause, i.e. benefit, good benefit in the World and benefit in the Hereafter. Second: Sharia law is returned to the mukallaf purpose. In addition to the division above, maqashid sharia is also divided according to its importance in human life. It can be implemented in three levels, namely dharuriyah, hajjiyah and tahsiniyah. This division is used to maintain the five basic elements of life in order to achieve human benefit [24].

\subsubsection{Maqashid Dharuriyah}

Maqashid Dharuriyah is something that must exist for the survival of life and human life (primary); if it is not fulfilled, it will cause damage in human life. Maqashid Dharuriyah is divided into five parts: Hifdzu al-din, hifdzu al-nafs, hifdz an-Nasl, hifdz al-Maal and hifdzu-al-'Aqli, as a condition for the creation of the benefit of one's life.

\subsubsection{Maqashid al- Hajiyyah}

Maqashid al-Hajiyyah is a further effort after the fulfilment of maqashid Daruriyah / basic needs, commonly referred to as secondary needs. This aims to fulfil various secondary needs of human life and if these life needs are not met, it will have a negative impact on humans. However, the consequences are not as large or as heavy as the consequences caused by the disappearance or nonfulfilment of Maqasid Daruriyah [25].

\subsubsection{Maqashid Tahsiniyah}

Maqashid Tahsiniyah is to use everything that is appropriate and away from bad behaviour, which aims at the perfection of maintaining the five main laws of maqashid sharia.

\section{RESULTS AND DISCUSSION}

\subsection{Sharecropping Agreement Form}

The sharecropping agreement carried out by the community in Sambirejo Village is an agreement in the form of an oral agreement.

\subsection{The Sharecropping Period}

Landowners and farmers do not determine the duration of the sharecropping agreement. In the sharecropping agreement carried out by farmers and landowners, the length of the agreement is not determined, thus, it does not include how long the agreement is carried out and when the agreement terminates.

\subsection{The contract rescission}

The period that is not specified in the sharecropping agreement causes it to continue with an unclear period. The sharecropping agreement ends if the farmer is unable to work on the land. Farmers end the agreement due to old age, health and other similar factors. The sharecropping agreement is terminated when the farmer is no longer able to work on the rice fields. To end the agreement, the farmers convey it directly to the landowner. Then, landowners can find other farmers to replace their cultivators. Then, the cultivation of rice fields is done by the next farmer. 
After the farmer terminates the contract with the landowner, the next farmer would be responsible for cultivation continuation. This occurs if the cultivation of the land has not been completed or not yet harvested, but if the agreement is terminated after harvest, the next farmer takes full responsibility for the land. In Sambirejo village, the death of one of the parties has never been the reason for the end of the sharecropping agreement.

If the farmer is not able to work on it, but still wants to continue the agreement, the cultivation will be continued by his child, where the offer of cultivation from farmers to children is carried out without notifying the landowners. The offer of responsibility is not notified to the landowner, because the landowner has given the rights to the farmer; as long as the farmer is still willing to be responsible for the land, the landowner does not interfere in the land cultivation.

In addition, a landowner can end the sharecropping if according to him, the farmer's job is unsatisfactory. The lack of effort by farmers in managing land can be seen from the poor yields. However, with poor harvest conditions, it is indeed caused by a lack of farmer performance, not from natural factors. Then the owner can end the agreement for sharecropping after the harvest period. According to the informant, no one has ever ended in the middle of the planting period; if the owner wants to take over the land, then it is done after the harvest period ends.

The end of the production sharing agreement is based on the harvest period; if the crop is not good, the owner can terminate the agreement and look for other farmers to work on the farm during the next harvest.

The agreement can end with the wishes of the landowner. If the landowner wants to manage his own land, the farmer returns the land to the owner after the harvest period.

\subsection{Provision of Production Tools}

The supply of materials and production equipment is provided by farmers. Production materials are materials needed in the processing of agricultural lands such as seeds, fertilizers, medicines and water, while production tools include plows, hoes and others.

\subsection{The Determination of Sharecropping Ratio}

The owner and farmer divide the harvest using a ratio of maro (half), mertelu (one third), merpapat (one quarter) and morolimo (one fifth). The sharecropping agreement system has not changed, except in the profit-sharing ratio adjusted to the agreement between landowners and farmers. The proportion is determined based on the planting season, namely as follows:

a. In the Rendeng or rainy season, agricultural products are divided by a ratio of $1: 3$ (mertelu).

b. In the Walikan season, which is between the rainy and dry seasons, the farmers get a share with a quarter ratio (merpapat).

c. In the Ghadu season or dry season, the results are divided by a ratio of one fifth (morolimo). The ratio during the dry season is one fifth, because during the dry season, the paddy fields lack water. Therefore,

farmers have to buy water to irrigate the land.

Division by half ratio only occurs if farmers and landowners want a share of half of the agricultural produce. Even though the season changes to the season of Rendeng, Walikan and Ghadu the distribution ratio does not change; it is still 50:50 following the wishes of both parties. Distribution with a ratio of 50:50 or maro is done by dividing the provision of materials and production tools or dividing the two costs to manage the land and then sharing the harvest into two.

\subsection{The Distributed of Yield}

The portion received by landowners can be shared in the form of money, grain or both. The results submitted by farmers to landowners can be in the form of money or grain. Distribution is carried out directly at the time of weighing, which is after the total harvest can be known. The gross yield will be deducted by the cost of cutting the rice and then divided according to the ratio agreed upon by both parties. Subsequently, the agricultural harvest shows a record of the calculation of the yield obtained to the landowner as evidence.

So, the division in the production sharing agreement in Sambirejo village is carried out after the harvest has been collected, which is in accordance with the agreed ratio or according to the season. The results are handed over to landowners in the form of money or grain depending on the agreement of the two parties.

\subsection{The Harvest Failure}

Cultivating land cannot be separated from the possibility of crop failure. The natural conditions are the cause of crop failure, such as during the dry season, there are obstacles to irrigate fields. This lack of irrigation is the reason for crop failure. As for pest attacks in the rainy season, farmers can prevent pests damage to the rice by doubling the pesticide. According to farmers, if they do not want crop failure due to the paddy being stricken with disease, farmers must increase the amount of pesticide.

Landowners usually do not get their share if there is a failure. From the explanation, the owner does not get a part of the harvest if the crop failed. When the cultivated land fails, the farmers are most disadvantaged. They bear a large loss because the costs incurred for working on the land are very high. From this, it is seen that the risk of crop failure is the responsibility of farmers. So when a crop fails, an agreement that has been formed cannot be fulfilled, namely the share in accordance with the profit sharing ratio. However, for sharecropping with maro, is carried out in accordance with the agreed ratio, which is half of the agricultural products. 


\subsection{Sharecropping Agreement According to Maqasid Syariah}

The implementation of the sharecropping agreement has existed since the time of the Prophet Muhammad and was practised by Muslims in that era, because the Prophet allowed it. Sambirejo village, Mantingan, Ngawi is an area that has been used in this agreement for a long time. So, when viewed from the number of farmers who carry out the agreement, there must be some benefits they receive, so that they can continue to implement this sharecropping agreement. In practice, this profit sharing can be analysed based on Maqhasid al-Haajiyah as the main medium for evaluating systems and practices that are decades old, hereditary activities that can be felt in general and also analysed based on maqhasid at-Tahsiniyyah- the second medium for analysing several landowners and sharecroppers.

\subsubsection{Maqhasid al-Haajiyyah}

According to Wahbah Zuhaili, maqhasid haajiyyah is the benefit that human beings need to facilitate them and raise their difficulties [26]. Maqhasid al-Haajiyah according to al-Syatibi, is something that should be there in order to implement it freely and avoid the difficulties. If this does not exist, it will not cause damage or death, but it will imply the difficulties [27]. According to 'Alaalul Faasi, haajiyyah is the facility that includes the affairs of Ibadah, custom, Mu'amalat and Jinaayaat. The Qur'an mentions:

The sharecropping in Sambirejo village, according to maqahasid al-Hajiyah in its sense, can provide ease and avoid the difficulties. Some of the facilities felt by landowners and farmers with the share of agricultural produce are as follows:

With a system of sharecropping, landowners feel maslahah in land ownership, because the land is used and does not feel difficult in the cultivation of the land, because if it is tackled by the landowners themselves, the ordinary results will be as much as losing funds and even experiencing losses caused by landowners less expert in managing their land. When viewed from the maslahah, the farmers do not have to rent land to work on because they will suffer from the expense and the results are not fixed. If the farmer uses a sharecropping system, then if the harvest reaps a profit, then the result is divided by both farmers and landowners.

\subsubsection{Maqhasid at-Tahsiiniyah}

According to al-Syatibi, at-Tahsiniyyah is a benefit related to good customs aligned with good morals/morality [28]. When viewed from the sharecropping practices of Sambirejo village, landowners and farmers feel the existence of the maqashid tahsiniyah, because with this sharecropping creates an honest custom and mutual trust between landowners and farmers, establishing akhlaqul karimah between them. Honesty is a highly regarded value by landowners and farmers of Sambirejo village, although they do not use authentic evidence or contract of agreement in sharecropping.

In addition, the nature of akhlaqul karimah is created from honesty and mutual trust between landowners and farmers in the presence of sincerity if the results of the estimation are less in line with the actual amount. So, there is no fight and hostility between the two; they always maintain harmony and peace between landlord and farmer in Sambirejo Village when executing the sharecropping agreement.

Thus, this sharecropping agreement becomes a hajiyah for them, because it has helped landowners to work on their land and assist farmers to get a job and earn a clear income, compared to land rent that only burdens the farmers.

Lastly, if it is reviewed from the maqashid at-tahsiniyah in the perspective of al-Syatibi that includes the perfection of the noble habits and virtues [29], Maqashid at-Tahsiniyyah is something which brings perfection in an activity that is done and if left behind it will not cause difficulties [30] As done by landowners and farmers in Sambirejo village, they feel comfortable and there is honesty in the deal, although not using authentic and identical data to benefit both.

\section{CONCLUSION}

In the implementation of the sharecropping agreement carried out in the village of Sambirejo, although it is not yet fully in accordance with the agreement on sharecropping in Islamic law, they use the habits of the local community. However, in the agreement, there have been helpful values, mutual trust and honesty that have led to benefit. The sharing agreement gives a lot of benefit to the landowners and farmers if it is viewed from the maqhasid al-Shari'ah in the haajiyyah level, which can eliminate the difficulties for the mukallaf. As the authors have examined, some of the landowners and farmers do not always use sharecropping agreements. Thus, this sharing agreement becomes a hajjiyah for them, because the existence of a sharecropping agreement has helped landowners to cultivate their land and helps farmers to get jobs and earn clear income, compared to land leasing, which only burdens farmers.

Finally, if viewed from maqashid at-tahsiniyah, which includes the perfection of customs and noble character and so is Maqashid at-Tahsiniyyah is something that brings perfection in an activity carried out and if abandoned it will not cause difficulties. As done by landowners and farmers in Sambirejo village, they feel comfortable and there is honesty in making agreements, even though they do not use authentic data and give both of them benefit.

\section{REFERENCES}

[1] A. Hakim, "Kearifan lokal dalam ekonomi islam (studi atas aplikasi al-urf sebagai dasar adopsi)", Akademika, Volume 8, Nomor 1, 2014.

[2] T. Wahyuningsih, "Sistem bagi hasil maro sebagai upaya mewujudkan solidaritas masyarakat", Jurnal Komunitas, 2011. 
[18] Dr. Wahbah Al-Zuhayli, Financial Transactions In

[3] D. Lubis, “Analisis pendapatan petani penggarap dengan akad muzara'ah dan faktor yang mempengaruhinya", Maqdis: Jurnal Kajian Ekonomi Islam -Volume 2, Nomor 1, 2017.

[4] D. Lubis, “Analisis pendapatan petani penggarap dengan akad muzara'ah dan faktor yang mempengaruhinya", Maqdis: Jurnal Kajian Ekonomi Islam -Volume 2, Nomor 1, 2017.

[5] Sugiyono, Memahami Penelitian Kualitatif, Bandung: ALFABETA, 2014.

[6] A.W. Muslich, Fiqh Muamalat, Ed.1, Cet. 4, Jakarta: Amzah, 2007.

[7] A. Sarwat, Seri Fiqih Islam Kitab Muamalat. Kampus Syariah, 2009.

[8] H.F. Asnawi, "Sistem muzara'a dalam ekonomi islam”, Millah Jurnal Studi Agama, Vol.4, No.2., 2005.

[9] Dr. Wahbah Al-Zuhayli, Financial Transactions In Islamic Jurisprudence, Vol. 2, Damascus: Dar Al-Fikr, 2002.

[10] Dr. Wahbah Al-Zuhayli, Financial Transactions In Islamic Jurisprudence, Vol. 2, Damascus: Dar Al-Fikr, 2002

[11] J.P. Nugraha, "Sistem muzara'ah sebagai alternatif pembiayaanpertanian di indonesia", Iqtishodia Jurnal Ekonomi Syariah, Vol. 1, No. 2, September 2016.

[12] V.R. Zainal, H. Alamsyah, Sugiharto, M.S. Antonio, Islamic Entrepreneurship maju, berkembang dan bertahan dengan teladan bisnis Rasulullah, Yogyakarta: BPFE, 2017.

[13] I. 'Alau al-Adin Abi Bakr bin Mas 'ud al-Kasani Al-Hanafi,, Bada' 'i al-Sana' 'i Fi Tartibi al-Syara' 'i, Ed.2, Vol.5, (Bairut: Dar al-Kitab al-Arabi,1974.

[14] Wizaratu al-Auqaf wa al-Syu'uni al- Islamiyah, alMausu 'ah al-Fiqhiyyah, Ed.1, Vol. 37. Kuwait: Tiba 'ah z|atu al-Salasil, 1418H-1997M.

[15] I. 'Alau al-Adin Abi Bakr bin Mas 'ud al-Kasani Al-Hanafi,, Bada' 'i al-Sana' 'i Fi Tartibi al-Syara' 'i, Ed.2, Vol.5, (Bairut: Dar al-Kitab al-Arabi,1974.

[16] Wizaratu al-Auqaf wa al-Syu'uni al- Islamiyah, alMausu 'ah al-Fiqhiyyah, Ed.1, Vol. 37. Kuwait: Tiba 'ah z|atu al-Salasil, 1418H-1997M.

[17] Dr. Wahbah Al-Zuhayli, Financial Transactions In Islamic Jurisprudence, Vol. 2, Damascus: Dar Al-Fikr, 2002.
Islamic Jurisprudence, Vol. 2, Damascus: Dar Al-Fikr, 2002.

[19] M. 'Abdul'atii Muhammad, Al-Maqashid asSyariah wa Atsariha Fii al-Fiqh al-Islamy, Jilid I. Kairo: Darul Hadist, 2007.

[20] H.S. Azhar, Maqashid Syariah 'Inda Imam Haromaini wa Atsaruhaa Fii at-Tasorrufaat alMaaliyah, Jilid I (Riyadh: maktabah ar-Rusyd, 2010.

[21] M. 'Abdul'atii Muhammad, Al-Maqashid asSyariah wa Atsariha Fii al-Fiqh al-Islamy, Jilid I. Kairo: Darul Hadist, 2007.

[22] A.H. al-Ghazalii Muhammad Bin Muhammad Bin Muhammad At-Tuusy, Syifaau al- Ghalil Fii bayaani as-Syabah wa al-Mukhayyal wa al-Masaaliki at-Ta'liil, Baghdad: al-Arsyaad, 1971.

[23] I. al-Syatibi Ibraahiim Bin Musa Bin Muhammad Al-Lakhmi, al- Muwaafaqqt Fii Usuli as- Syariah, Jilid II, Saudi: Wazaarah al-Awqaf, 2014.

[24] V.R. Zainal, H. Alamsyah, Sugiharto, M.S. Antonio, Islamic Entrepreneurship maju, berkembang dan bertahan dengan teladan bisnis Rasulullah, Yogyakarta: BPFE, 2017.

[25] V.R. Zainal, H. Alamsyah, Sugiharto, M.S. Antonio, Islamic Entrepreneurship maju, berkembang dan bertahan dengan teladan bisnis Rasulullah, Yogyakarta: BPFE, 2017.

[26] W.Az-Zuhaili, Ushulul Fiqh al-Islami, Juz 1, Damaskus: Daar al-Fikr, 1406 H-1986M.

[27] I. al-Syatibi Ibraahiim Bin Musa Bin Muhammad Al-Lakhmi, al- Muwaafaqqt Fii Usuli as- Syariah, Jilid II, Saudi: Wazaarah al-Awqaf, 2014.

[28] I. al-Syatibi Ibraahiim Bin Musa Bin Muhammad Al-Lakhmi, al- Muwaafaqqt Fii Usuli as- Syariah, Jilid II, Saudi: Wazaarah al-Awqaf, 2014.

[29] I. al-Syatibi Ibraahiim Bin Musa Bin Muhammad Al-Lakhmi, al- Muwaafaqqt Fii Usuli as- Syariah, Jilid II, Saudi: Wazaarah al-Awqaf, 2014.

[30] A. 'Abdi ar-Rohman al-Kholil bin Ahmad bin 'Amru bin Tamiim al-Faraahiidii Al-Basyarii, Kitaab al-'Aini, Jilid. 8, Daar wamaktabah al-Hilaal. 